\title{
CONTROLLING SYSTEMATIC ERRORS IN ROCK TESTING BY MEASUREMENT UNCERTAINTY ANALYSIS
}

UDC: 621.317

Original Scientific Paper

\author{
Bulent TUTMEZ \\ School of Engineering, Inonu University, Malatya, Turkey \\ E-mail: bulent.tutmez@inonu.edu.tr
}

Paper received: 05.03.2018.; Paper accepted: 19.05.2018.

\begin{abstract}
In engineering and fundamental sciences, many important decisions are based on the results of quantitative measurements. When an observation result is stated, it is also required to determine the uncertainty associated with the observation. A measurement uncertainty analysis comprises of random and systematic components. Different from the random fluctuations, systematic uncertainties are resourced from the specifications, environmental conditions, calibration and other heuristic critical factors. This study assesses the systematic and random effects which create some uncertainty on a Schmidt Hammer (SH) rebound hardness test. In particular, as the certain probability terms, the systematic uncertainty component is focused and its volume has been appraised from a control framework. The importance of elemental uncertainty and coverage term are discussed from a statistical control perspective. In the same ground, the effective number of degrees of freedom is also evaluated. In this way, the importance of the fixed error sources has been appraised based on statistical control perspective. The use of an uncertainty term as a measurement parameter in testing-based decision making can provide some reliable and realistic information for engineering risk management and quality control.
\end{abstract}

Key words: Measurement uncertainty, Systematic error, Schmidt hammer, Rock mechanics.

\section{INTRODUCTION}

Rock mechanics is an applied branch of the material sciences. Rocks are natural substances whose processes of generation and history of alteration are complex and generally unknown. To provide some reliable measurements, precise and specific experimental approaches are devised in rock engineering. When investigating the fundamental properties of rocks, it is of utmost importance to reduce the extrinsic fluctuation of data and to increase the reproducibility of experimental measurements. With this design, the selection of suitable uniform rock specimens and the use of suitable devices for providing reliable experimental test measurements with high accuracy are essential for controlling the rock behaviours (Mogi, 2007).

There are many test methods which can be used in laboratories to determine the hardness of engineering materials. A hardness value of rock or concrete is precisely related to the material heterogeneity (Amaral et al., 1999). The Schmidt Hammer ( $\mathrm{SH})$ is a simple, non-destructive and inexpensive test used for this measurement purpose. As discussed in the ISRM (The International Society for Rock Mechanics) the suggested method (Aydin, 2009), SH rebound hardness is one of the most frequently used indexes in rock mechanics for predicting the modulus of elasticity (E) and the uniaxial compressive strength (UCS) of rock both in laboratory conditions and in site. The $\mathrm{SH}$ is also used for predicting the walls and assessing the workability, excavability of rock formations by mechanical means (cutting and fragmentation processes in quarrying, drilling and tunnelling). Because the $\mathrm{SH}$ test is a reference test to determine some critical design parameters in rock engineering, accuracy and variability of the measurements gain critical importance.

To provide a fundamental or engineering science measurement, three main steps are followed: 
selection and installation of devices, observation and recording. It is out of the question to obtain measurement data that are the same as actual values overwhelmingly. It is natural to record some fluctuations in the measurement results. The main reasons for the variability encountered could be the accuracy limitations of measurement equipment, environmental conditions, calibration and statistical errors. A scientific methodology used for measuring a physical quantity should consider the relations between their values. In practice, all measured values are influenced by uncertainty. Understanding the source of uncertainty, appraising its extent, and suitably considering in data analysis, are fundamental stages for evaluating the global accuracy of physical laws and the degree of reliability of their technological applications (Fornasini, 2018).

In measurement science, two main types of uncertainty are specified: random and systematic uncertainty. A random uncertainty depends on the heterogeneity, number of measurements and reading errors. Random error can be statistically modelled and estimated. In other respects, systematic uncertainty addresses an explicit tendency or regularity in the process of measurement. Systematic errors can be resourced from calibration, operator, environment and method. Although this type of uncertainty can also be predicted and adjusted, it may create some dramatic, constant impact on measurement outcome (Hibbert, 2007).

Using uncertainty quantification in rock strength measurement can provide some novel statistical methodologies (Debese et al., 2012; Contreras et al., 2018). In recent years, many studies have been presented in literature on combining measurement uncertainty methodology and experimental rock mechanics (Kuhinek et al., 2011; Tutmez, 2017). In these works, the amount of uncertainties in rock testing parameters has been evaluated by general measurement uncertainty framework. In this study, together with the random uncertainty, dealing with the systematic uncertainties and providing some information for a potential control strategy is the main motivation of this study. As applied in a statistical control analysis, measurement uncertainty analysis has been mainly performed on the systematic uncertainties. By this way, the importance of the fixed error sources has been appraised based on statistical control perspective.

In the next section of this paper, the hardness measurement and uncertainty evaluation methodology will be introduced. After that, a case study will be given. In the last section a brief discussion and conclusion will be presented.

\section{METHODOLOGY}

\section{Schmidt Hammer (SH) Rebound Hardness Test}

The Schmidt Hammer test has been widely utilized for testing the quality of concrete and rocks. It has been increasingly employed worldwide due to its simplicity, rapidity, non-destructiveness and portability (Karakus \& Tutmez, 2006). As a portable device, the Schmidt rebound hammer can be used directly on a rock surface. By this device spring driven cylindrical hammer rebounds off the rock surface; the rebound distance is considered to be a measure of the rock quality (Hudson \& Harrison, 1997). The SH comprises of a springloaded piston which is released when the plunger is pressed against a surface such as rock or concrete. Figure 1 shows a general view of a $\mathrm{SH}$ test equipment.

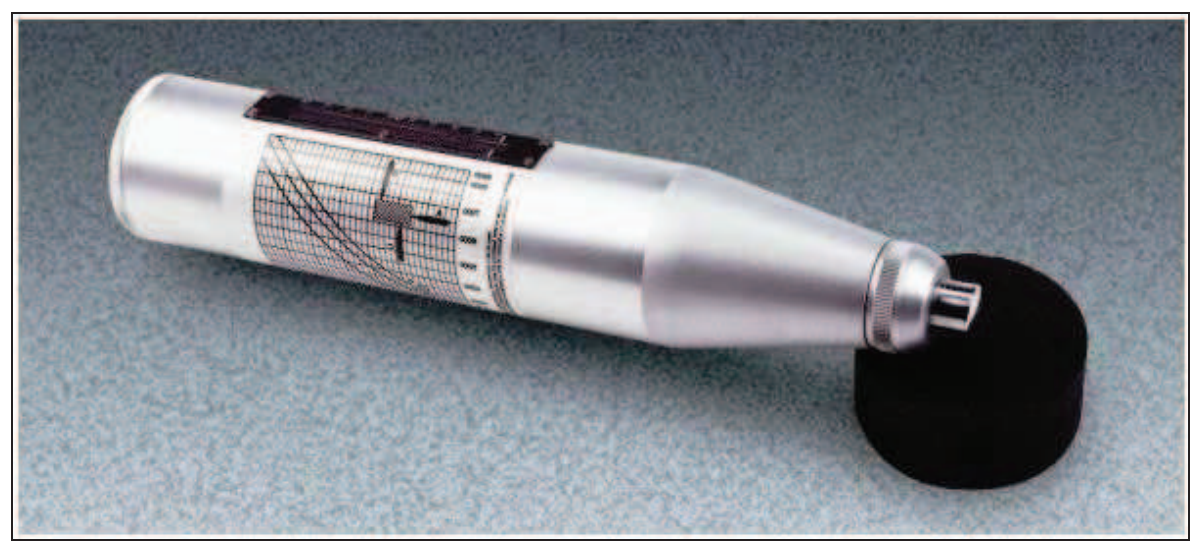

Figure 1: Schmidt Hammer test equipment. 
As described in the recent ISRM suggested method (Aydin, 2009), the measurements can be used to identify the correlations between the $\mathrm{SH}$ rebound measurements $(\mathrm{R})$ and the uniaxial compressive strength (UCS) and the modulus of elasticity (E). Therefore, together with the accuracy, variability and regularity of the measurements should be appraised.

\section{Measurement Uncertainty Analysis}

The statistical quality control (SQC) procedures can be established both ensuring process stability and obtaining data for use in the evaluation of measurement uncertainties. Measurement data cannot be regarded as true values of the quantity to be measured due to random (repeatability) and systematic errors. If we represent repeatability errors with $\epsilon$ and systematic errors with the $\beta$, an expression can be written for a measured value as follows (Shaw, 2017):

$$
\begin{aligned}
& x=x_{\text {true }}+\varepsilon_{1}+\varepsilon_{2}+\ldots \\
& ++\varepsilon_{L}+\beta_{1}+\beta_{2}+\ldots+\beta_{M} .
\end{aligned}
$$

We denote $x_{\text {true }}=\langle x\rangle+\alpha$, the following short form can be written:

$$
x=\langle x\rangle+\alpha+\varepsilon+\beta .
$$

Where $\alpha$ represent the variations in the measured variable and $\langle x\rangle$ is accepted as a constant. In eq. (2), fluctuations and repeatability error terms depend on the number of measurements. Therefore,

$$
\bar{x}=\langle x\rangle+\sum_{i=1}^{N} \frac{\alpha_{i}}{N}+\sum_{i=1}^{N} \frac{\varepsilon_{i}}{N}+\beta .
$$

It should be noted that the term $\beta$ (systematic error) is independent from $N$. Finally the combined uncertainty is expressed as follows (JCGM, 2008):

$$
u_{\bar{x}}=\left(s_{\bar{x}}^{2}+b_{\bar{x}}^{2}\right)^{1 / 2} \text {. }
$$

In eq. (3), $b_{\bar{x}}=b_{x}$ and $s_{\bar{x}}$ is the repeatability uncertainty. The expanded uncertainty is structured together with the coverage term as follows:

$$
U_{\bar{x}}=k \cdot u_{\bar{x}},
$$

where, $k$ represents the coverage factor. For $95 \%$ confidence, $k$ is about 2 . If the number of data is limited, the following Welch-Satterthwaite formula can be utilized for determining the effective number of degrees of freedom $(v)$ :

$$
v_{e f f}=\frac{s_{x}^{2}+\sum_{g} b_{x, g}^{2}}{\frac{s_{x}^{4}}{v_{s_{\bar{x}}}}+\sum_{g} \frac{b_{x, g}^{4}}{v_{b_{x, g}}}} .
$$

In eq (6), $v_{s_{\bar{x}}}=N-1$.

In many times, a systematic uncertainty evaluation contains making a best prediction based on expert judgment and all available information such as calibration and standard values. When a systematic effect in the measurement process has been stated and quantified, a quantity should be included in the measurement model for controlling or elimination.

\section{CASE STUDY}

\section{Data Set and Outlier Identification}

The applications were performed by a real data set derived from the Hacettepe University Rock Mechanics Laboratory (Ulusay et al., 2005). The data set includes two different samples. 10 rebounds have been considered for the analyses. The applications have been particularly based on the evaluation of the systematic effect.

Both statistical quality control and measurement uncertainty analyses require determining the outliers in input data. The potential outliers in the experimental rock mechanics measurements can be resourced from different factors such as sampling, heterogeneous nature or manual evaluation. For this implementation, the modified "Thompson $\tau$ Method" has been employed (Shen \& Yang, 2015). An observation is considered to be an outlier in accordance with the following condition:

$$
\delta=\left|x_{i}-\bar{x}\right| \varnothing \geq \tau \cdot S_{x}
$$

The rejection region, $\tau$ is derived from student- $t$ distribution. $S_{x}$ denotes the standard deviation. If it is not satisfied, then the data point is not an outlier. As a result of the implementation, the relationship 
between delta $(\delta)$ values and the laboratory measurements is illustrated in Figure 2. As can be recorded by Figure 2, there is no value above the horizontal value and no potential outlier value is observed (Shaw, 2017).

\section{Systematic Uncertainty Components}

The identification of the source of the systematic error can impact on its estimation and treatment. In this rock mechanics test, operator bias, resolution uncertainty and calibration uncertainty were considered as the systematic uncertainty sources. The suggested method is to calibrate the systematic errors by certain probabilities. This approach allows us to utilize some statistical properties to appraise the systematic effects. To denote these uncertainties, different type probability density functions have been adopted.

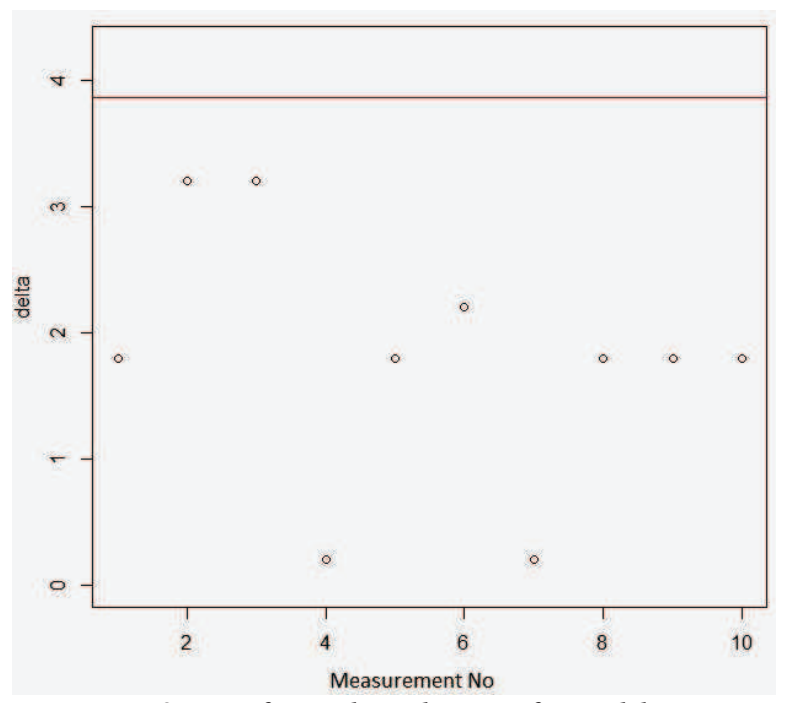

Figure 2: Uniform distribution for calibration error

The operator bias resourced from the user could be taken into consideration to be normally distributed error source (NASA, 2010). For this systematic uncertainty, bias for operator can be stated using \pm 0.5 limits at $90 \%$ containment probability. Figure 3 illustrates this uncertainty component.

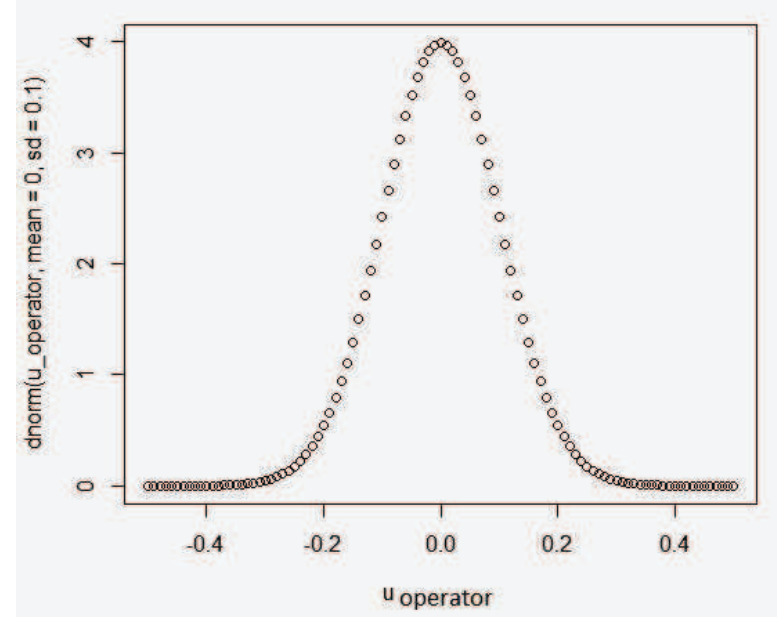

Figure 3: Normal distribution of operator error

By using the inverse normal distribution function $\Phi^{-1}$, the uncertainty is presented as follows:

$$
u=\frac{a}{\Phi^{-1}\left(\frac{1+p}{2}\right)}
$$

where $a$ denotes the limits and $p$ value corresponds the confidence. Measurement bias can be calculated as follows:

$$
u_{\text {bias }}=\frac{0.5}{\Phi^{-1}[(1+0.90) / 2]}=0.304
$$

The connection between plunger and hammer is the critical part for the operation. The hammer is calibrated by calibrators with an accuracy of at least \pm 0.5 . Because the values for this measurement close to center more likely than near the bounds, a triangle distribution as in Figure 4 can be fitted. 


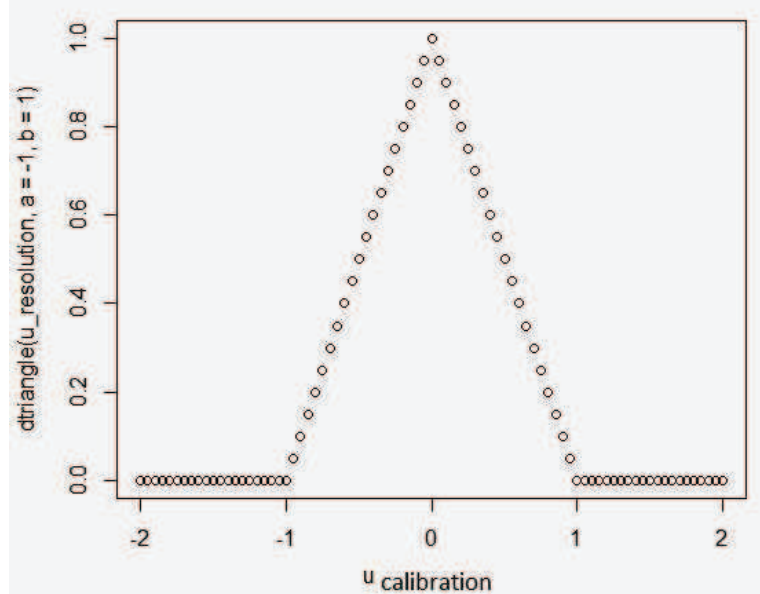

Figure 4: Symmetric triangular distribution for calibration

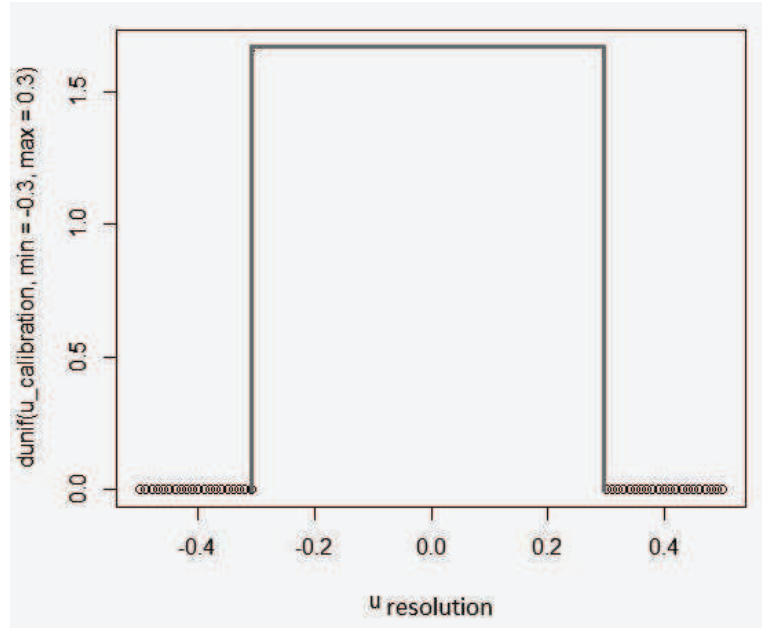

Figure 5: Uniform distribution for resolution error

The standard uncertainty has been obtained by $u_{c a l}=a / \sqrt{6}$ as follows:

$$
u_{c a l}=\frac{0.5}{\sqrt{6}}=0.204 . .204
$$

The resolution uncertainty is an equipmentdependent uncertainty and it can be specified heuristically from the specifications of the digital hammer as $1 \quad( \pm 1)$ containment limit. The resolution uncertainty can be processed as a uniformly (i.e. rectangular) distribution error (Figure 5) by $u_{\text {res }}=a / \sqrt{3}$ with $100 \%$ containment probability (Tutmez, 2017):

$$
u_{r e s}=\frac{1}{\sqrt{3}}=0.577 \text {. }
$$

\section{Results and Discussion}

To provide the effective number of degrees of freedom $v$, the expression given in Eq. (6) and Student's $t$ table has been used. In the expression, the relative uncertainty of each error source was considered as $5 \%$. As a result, the effective number of degrees of freedom was calculated as $v=10$. For a $95 \%$ confidence level, the coverage factor $k$ was computed as $t_{v, 1-\frac{\alpha}{2}}=2.228$. In practice, the value of $k$ relies on some factors such as the number of data points and the confidence level $P$. In the conventional applications, the relative uncertainties of the systematic uncertainties are not known. If the degree of freedom is greater than about 10 , the coverage factor will be close to 2 . This trend is depicted in Figure 6.

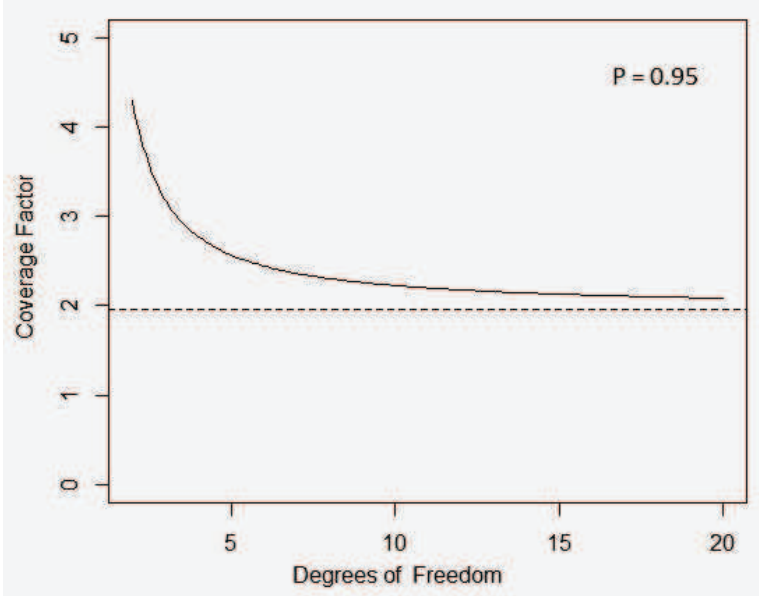

Figure 6: Functional relationship between coverage factor and DoF

For the Schmidt Hammer rebound measurements, control limits have been provided as $\bar{R}=28.4 \pm 2.148$. The relative uncertainty of the average $\mathrm{SH}$ measurement can be calculated the expanded uncertainty of FH divided by $\mathrm{SH}$ mean value as follows:

$$
\begin{aligned}
& \text { RelativeUncertainty }=\frac{U_{\bar{x}}}{\bar{x}}(P \%) \\
& \text { RelativeUncertainty }=\frac{2.148}{28.4}=0.076 .
\end{aligned}
$$

Determination of an uncertainty interval using 95\% confidence level and average value provides a plot to appraise the control limits. Figure 7 shows this plot. As seen in Figure 7, the second and the third measurements are below the average level. In 
addition, the sixth measurement has been recorded on the bottom level.

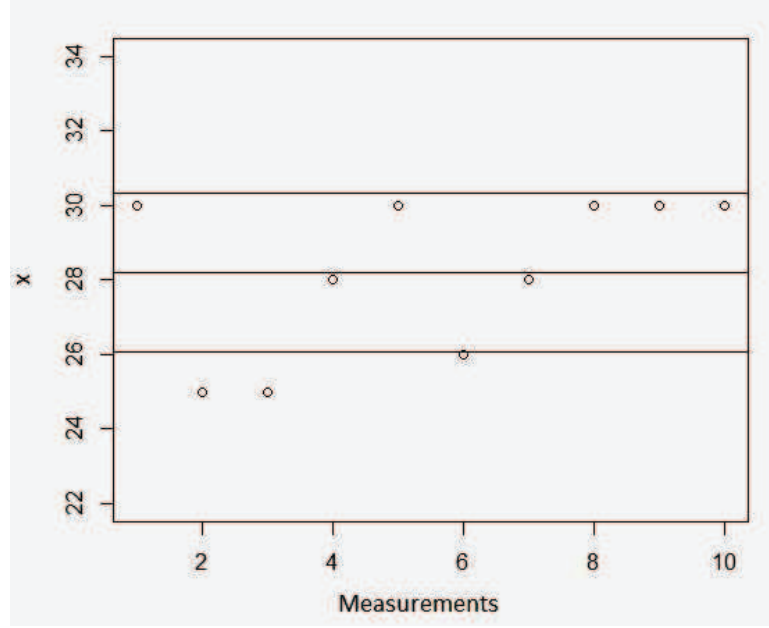

Figure 7: Control limits for average rebound measurements.

From the applications, random and systematic uncertainty components have been calculated as 0.462 and 0.467 , respectively. Because the rock is a heterogeneous natural material, a big random (repeatability) uncertainty could be expected. However, the major component of the uncertainty has been recorded as a systematic uncertainty.

\section{CONCLUSIONS}

In the company with the random uncertainty, the systematic uncertainties have been quantified by probability distributions and, in order to establish a control strategy, some new information have been provided based on measurement uncertainty analysis. The study is mainly focused on the systematic effects and the importance of the fixed error sources has been explored based on statistical control perspective.

The systematic and random effects generate some uncertainty on a Schmidt Hammer (SH) rebound hardness test but they have been appraised. In particular, systematic uncertainties are quantified by measurement uncertainty analysis methodology. The applications showed that the effect of systematic errors on the final measurement value has notable contribution.

Based on this study, the contribution of the fixed error sources has been evaluated from a statistical control perspective. Use of the result of measurement uncertainty evaluation as a component in decision making can provide some reliable and realistic information for engineering risk management and quality control.

\section{REFERENCES}

Amaral, P. M., Rosa, L. G., \& Fernandes, J. C. (1999). Determination of Schmidt rebound hardness consistency in granite. International Journal of Rock Mechanics and Mining Sciences, 36(6), 833-837.

Aydin, A. (2009). ISRM Suggested method for determination of the Schmidt hammer rebound hardness: Revised version. International Journal of Rock Mechanics and Mining Sciences, 46(3), 627634.

Contreras, L.F., Brown, E.T., \& Ruest, M. (2018). Bayesian data analysis to quantify the uncertainty of intact rock strength. Journal of Rock Mechanics and Geotechnical Engineering, 10(1), 11-31.

Debese, N., Seube, N., \& Heydel, L. (2012). Qualitative and quantitative description of multibeamechosounder systematic errors on rocky areas. Marine Geodesy, 35(3), 306-321.

Fornasini, P. (2008). The Uncertainty in Physical Measurements. New York: Springer.

Hibbert, D.B. (2007). Systematic errors in analytical measurement results. Journal of Chromatographya A, 1158 (1-2), 25-32.

Hudson, J.A., \& Harrison, J.P. (1997). Rock Mechanics. Oxford: Pergamon.

JCGM. (2008). Evaluation of Measurement DataGuide to the Expression of Uncertainty in Measurement. Paris: BIPM.

Karakus, M., \& Tutmez, B. (2006). Fuzzy and multiple regression modelling for evaluation of intact rock strength based on point load, Schmidt hammer and sonic velocity. Rock mechanics and rock engineering, 39(1), 45-57.

Kuhinek, D., Zorić, I., \& Hrženjak, P. (2011). Measurement uncertainty in testing of uniaxial compressive strength and deformability of rock samples. Measurement Science Review, 11(4), 112117.

Mogi, K. (2007). Experimental Rock Mechanics. London: Taylor\&Francis

NASA.(2010). Measurement Uncertainty Analysis, Principles and Methods. Washington DC: National Aeronautics and Space Administration.

Shaw, B.D. (2017). Uncertainty Analysis of Experimental Data with R. Boca Raton: CRC Press.

Shen, Q., \& Yang, R. (2015, December). Thompson-

Tau Outlier Detection Method for Detecting Abnormal Data of Listed Pharmaceutical Companies in China. In Computational Intelligence and Design (ISCID), 2015 8th International Symposium on (Vol. 1, pp. 379-382). IEEE.

Tutmez, B. (2017). Measurement uncertainty analysis for compressive loading-based ultrasonic wave propagation. Nondestructive Testing \& Application, 32(3), 269-285. 
Tutmez, B., \& Unver, B. (2017). Uncertainty-based analysis for agreement of tensile strength measurement procedures. Geotechnical Testing Journal, 40(3), 506-514.
Ulusay, R., Gokceoglu, C., \& Binal, R. (2005). Rock Mechanics Laboratory Tests (in Turkish). Ankara: JMO.

\title{
KONTROLISANJE SISTEMSKIH GREŠAKA U TESTIRANJU TVRDOĆE KAMENA, PRIMENOM ANALIZE MERNE NESIGURNOSTI
}

\begin{abstract}
U inženjerstvu i osnovnim naukama mnoge važne odluke zasnivaju se na rezultatima kvantitativnih merenja. Kada se, međutim, daje rezultat posmatranja, neophodno je naznačiti i nesigurnost povezanu sa ovim posmatranjem. Analize merne nesigurnosti uključuju nasumične (slučajne) i sistemske komponente. Za razliku od slučajnih odstupanja, sistemske nesigurnosti potpiču od specifikacija, uslova okoline, kalibracije i drugih heurističkih kritičnih faktora. Ova studija ocenjuje sistemske i slučajne efekte koji stvaraju nesigurnost u testiranju tvrdoće kamena pomoću Schmidt Hammer (SH) testa. Konkretno, kao određeni pojmovi verovatnoće, sistemska komponenta nesigurnosti je fokusirana i njen značaj se procenjuje iz ugla kontrole. Značaj elementarne nesigurnosti i koncepta pokrivenosti razmatra se iz perspektive statističke kontrole. $U$ istom se procenjuje i efikasan broj stepeni slobode. U ovom smislu, značaj sistemskih izvora grešaka ocenjen je sa stanovišta perspektive statističke kontrole. Korišćenje nesigurnosti kao referentnog mernog parametra za donošenje odluka na osnovu testiranja, može pružiti neke pouzdane i realne informacije za upravljanje tehničkim rizikom i kontrolu kvaliteta.
\end{abstract}

Ključne reči: Merna nesigurnost, Sistematska greška, Schmidt Hammer, Mehanika kamena. 